\title{
ПОКРАЩЕННЯ ПРОДУКТИВНОСТІ М'ЯСО-ЯЄЧНИХ КУРЕЙ ВІТЧИЗНЯНОЇ СЕЛЕКЦІЇ
}

\author{
Бондаренко Юрій Васильович \\ доктор біологічних наук, просресор \\ Сумський національний аграрний університет \\ ORCID: 0000-0002-5746-379X \\ E-mail: yuvbond@ukr.net \\ Хвостик Віктор Павлович \\ доктор сільськогосподарських наук \\ Інститут розведення і генетики тварин \\ імені М.В.Зубця НАAН \\ ORCID: 0000-0002-8107-4831 \\ E-mail: lab29@meta.ua
}

Робота виконана на м'ясо-яєчних курях вітчизняної селекції, племінна робота з якими проводилася в ДДСП НААН. За тривалого розведення "у собі» методами масової селекції господарсько корисні ознаки м'ясо-яєчних курей вітчизняної селекції дещо погіршилися. У зв'язку з цим виникла нагальна необхідність покращення основних продуктивних ознак м'ясо-яєчних курей за схрещування з птицею високопродуктивних кросів закордонної селекції. Схрещування м'ясо-яєчних курей з півнями батьківської форми кросу „Кобб-500” суттєво збільшило живу масу гібридних нащадків $F_{1}$, масу яєць в 52тижневому віці курей, але зменшило несучість порівняно з вихідною базовою популяцією. Гібридизація м'ясо-яєчних курей 3 півнями кросу „Росс-308” збільшила тільки енергію росту молодняку $F_{1}$ до 10-тижневого віку. Розведення гібридів $F_{1}$ „у собі” та зворотне схрещування самок $F_{1}$ з переярими півнями кросу „Кобб-500” сприяло підвищенню живої маси у нащадків $F_{2}$, маси яєць, але при цьому знизило несучість на 7,7-10,1 яєць (або 8,19-11,03\%) порівняно з вихідною материнською формою. Розведення „росівськоі” птиці $F_{1}$ „у собі” та зворотне схрещування гібридних самок $F_{1}$ з переярими півнями кросу „Росс-308” сприяло покращенню живої маси потомків $F_{2}$ на 5,21-11,89\%, несучості на 6,2-7,4 яєць порівняно з м'ясояєчними курьми базової популяції. При об'єднанні птиці різних генотипних груп було створено гетерогенну субпопуляцію, продуктивні ознаки якої поліпшилися у порівнянні з попередніми поколіннями $\left(F_{9}-F_{11}\right)$ птиці вихідної базової популяції. Порівняно з попередніми поколіннями збільшилася жива маса птиці в молодому (півників на 100-310 г, курочок - на 50-180 г) та дорослому віці (півнів на 130-730 г, курей на 150-650 г), маса яєць у різні вікові періоди, несучість (на початкову несучку на 14,5-27,2 яєць, на середню - на 14,3-26,2 яєць), життєздатність молодняку ( на 5,0-7,3\%) і дорослого поголів'я (на 5,5-7,6\%). Відтворні якості курей створеної гетерогенної популяції були добрими.

Ключові слова: м'ясо-яєчні кури, господарсько корисні ознаки, півні імпортних м'ясних кросів, схрещування.

DOI: https://doi.org/10.32845/bsnau.lvst.2020.2.5.

М'ясо-яєчна птиця вітчизняної селекції тривалий час розводилася „у собі” методами масової селекції, внаслідок чого її господарськи корисні ознаки дещо погіршилися й тому негайно потребували поліпшення. Тому виникла нагальна необхідність покращення основних продуктивних ознак м'ясо-яєчних курей за схрещування з птицею високопродуктивних кросів закордонної селекції.

Оскільки при виведенні м'ясо-яєчних курей на різних етапах селекції використовувалися плідники кросів „Кобб500” та „Росс-308”, була поставлена задача оцінити ефективність впливу їх спадковості на експресію господарсько корисних якостей м'ясо-яєчної птиці. У доступній літературі не знайдено даних про використання у селекційній роботі півнів фінального гібриду (прямим призначенням яких $\epsilon$ відгодівля на м'ясо у молодому віці) для покращення продуктивних ознак м'ясо-яєчних курей, тому було вирішено практично вивчити це питання.

У різних галузях вітчизняного тваринництва впродовж останнього часу широко використовують закордонний селекційний матеріал для проведення різних типів схрещування, які застосовують як при створенні нових селекційних досягнень, так і при поліпшенні тих чи інших окремих господарськи корисних ознак у існуючих порід тварин різних видів [1-5].

У птахівництві також для покращення продуктивних показників птиці вітчизняної селекції широко використовують схрещування з високопродуктивними імпортними кросами $[6-9,11-13]$.

За відсутності в Україні племінних заводів, індивідуальної селекції з м'ясо-яєчними курми, відсутності власних генетичних ресурсів курей м'ясних кросів, для визначення потенційної можливості ефективного використання у селекційно-племінній роботі м'ясних півнів фінальних гібридів, неодноразового залучення їх до селекційного процесу для покращення господарсько корисних ознак м'ясо-яєчних курей вітчизняного генофонду, зменшення витрат на придбання селекційного матеріалу прабатьківських чи батьківських форм набуває актуальності пошук нетрадиційних шляхів покращення м'ясо-яєчної птиці для присадибних і фермерських господарств. У зв'язку з цим було поставлено завдання у практичному аспекті вивчити результативність ввідного схрещування самців фрінального гібриду кросу „Росс-308” 3 м'ясо-яєчними курми вітчизняної селекції. До того ж, в Україні птиця батьківських стад та бройлерів м'ясних курей провідних імпортних кросів „Кобб-500” та „Росс-308” набула широкого розповсюдження [10, 14], у зв'язку з чим актуальним постає питання залучення її до селекційного процесу для оцінки впливу спадковості на експресію продуктивних якостей вітчизняної м'ясо-яєчної птиці при одночасному збереженні характерної для неї високої адаптаційної здатВісник Сумського національного аграрного університету 
ності. Тому метою досліджень $€$ покращення господарсько корисних ознак м'ясо-яєчних курей вітчизняного генофонду за схрещування з генетичним матеріалом зарубіжної селекції.

Матеріали та методи досліджень. Проведено схрещування півнів м'ясних кросів „Кобб-500” та „Росс-308” з м'ясо-яєчними курми $\left(F_{9}\right)$ породи плімутрок білий, селекційна робота з якими проводилася в племінному заводі Державної дослідної станції птахівництва НААН. Внаслідок проведених схрещувань отримали нащадків першої генерації $\left(F_{1}\right)$ відповідно груп „К-1” та „К-2”. За зворотного схрещування переярих півнів кросів „Кобб-500” та „Росс-308” з молодими гібридними курми $\mathrm{F}_{1}$ груп „К-1” і „К-2” одержали гібридів другого покоління $\left(\mathrm{F}_{2}\right)$ відповідно груп „К-51” та „К-32”. Крім цього, гібриди $\mathrm{F}_{1}$ груп „К-1” і „К-2” розводилися „у собі”, внаслідок чого отримали їх нащадків $\mathrm{F}_{2}$ груп „K-11” та „K-22”. Шляхом об'єднання курей вихідної родинної форми, нащадків $F_{2}$ різних груп створено синтетичну популяцію м'ясояєчних курей, умовно позначену як групу „К-5”.

Результати досліджень. На першому етапі роботи за штучного осіменіння м'ясо-яєчних курей поліспермою півнів батьківської форми кросу „Кобб-500” заплідненість яєць становила $78,2 \%$, виводимість яєць - 85,8\%, вивід молодняку був на рівні 67,1\%. При розведенні м'ясо-яєчної птиці локальної популяції „K” (F9) „у собі” отримано дещо вищі відтворні якості: заплідненість яєць на рівні 80,3\%, виводимість яєць - 91,2\%, вивід молодняку склав 73,2\%. Дещо менші значення відтворних якостей отримано у групі курей, яких осіменяли поліспермою півнів фінального гібриду „Росс-308”: заплідненість яєць становила 71,0\%, виводи- мість яєць - 87,9\%, вивід молодняку - 62,5\%. Одержані результати показали реальну можливість отримання спермопродукції досить гарної якості від півнів-бройлерів у віці 12 місяців, прямим призначенням яких $є$ відгодівля для отримання м'яса в дуже молодому віці (6-7 тижнів життя), та одержання від них життєздатних нащадків.

Схрещування м'ясо-яєчних курей з півнями батьківської фрорми кросу „Кобб-500” суттєво збільшило живу масу гібридних нащадків $F_{1}$ на всіх етапах раннього онтогенезу (на 6,84-33,48\%), вірогідно збільшило масу яєць в 52тижневому віці курей на 1,8 г, але зменшило несучість на 18,8 яєць порівняно з вихідною базовою популяцією.

Гібридизація м'ясо-яєчних курей 3 півнями кросу „Росс-308” збільшила тільки енергію росту молодняку $F_{1}$ до 10-тижневого віку (на 3,14-14,54\%), але зовсім не вплинула на господарсько корисні ознаки дорослої птиці, які були на рівні вихідної материнської форми.

На подальшому етапі роботи за отриманими результатами проведених досліджень можна заключити, що розведення „кобівських” гібридів $F_{1}$ „у собі” та зворотне схрещування гібридних самок $\mathrm{F}_{1}$ з переярими півнями кросу „Кобб500" сприяло підвищенню у нащадків $\mathrm{F}_{2}$ живої маси у ранньому онтогенезі (2-17 тижнів) на 3,35-15,28\%, у дорослому віці (52 тижні) - на 8,23-23,33\%, маси яєць у молодому (на 1,06-1,23 г або 2,34-2,72\%) та дорослому віці (на 1,55-1,93г або 2,48-3,09\%), але при цьому знизило несучість на 7,710,1 яєць (або 8,19-11,03\%) порівняно з вихідною материнською формою (табл. 1).

Господарськи корисні ознаки курей дослідних груп

\begin{tabular}{|c|c|c|c|c|c|c|c|c|c|}
\hline \multirow{3}{*}{ Група курей } & \multicolumn{4}{|c|}{ Жива маса, кг } & \multicolumn{2}{|c|}{ Мaca яєць, г } & \multirow{3}{*}{$\begin{array}{l}\text { Несучість за } 30 \\
\text { тижнів, яєць }\end{array}$} & \multirow{3}{*}{$\begin{array}{c}\text { Заплідненість } \\
\text { яєць, \% }\end{array}$} & \multirow{3}{*}{$\begin{array}{c}\text { Вивід } \\
\text { молодняку, } \\
\%\end{array}$} \\
\hline & \multicolumn{2}{|c|}{17 тижнів } & \multicolumn{2}{|c|}{52 тижні } & \multirow{2}{*}{24 тижні } & \multirow{2}{*}{52 тижні } & & & \\
\hline & $\hat{0}^{2}$ & o & $\hat{0}^{2}$ & 우 & & & & & \\
\hline „K”, $F_{11}$ & 2,88 & 2,14 & 4,03 & 3,16 & 45,3 & 62,6 & 101,7 & 91,8 & 82,9 \\
\hline „K-11” & 3,12 & 2,27 & 4,50 & 3,42 & 46,5 & 64,5 & 91,6 & 83,7 & 79,1 \\
\hline „K-22” & 3,03 & 2,30 & 4,32 & 3,33 & 46,7 & 61,9 & 109,1 & 77,3 & 72,0 \\
\hline „K-51” & 3,32 & 2,29 & 4,97 & 3,66 & 46,3 & 64,1 & 94,0 & 89,0 & 80,5 \\
\hline „K-32” & 3,20 & 2,33 & 4,74 & 3,50 & 46,6 & 61,6 & 107,9 & 75,9 & 65,5 \\
\hline
\end{tabular}

Тоді як, розведення „росівської” птиці $F_{1}$ „у собі” та зворотне схрещування гібридних самок $F_{1} 3$ переярими півнями кросу „Росс-308” покращило живу масу потомків у 12-тижневому віці на 7,37-11,89\%, у 17-тижневому - на 5,21$11,11 \%$, не здійснило значного впливу на масу яєць у нащадків $F_{2}$ (вона була на рівні вихідної материнської форми), але сприяло підвищенню несучості на 6,2-7,4 яєць або 6,107,28\% порівняно з м'ясо-яєчними курми базової популяції.

Заплідненість яєць найвищою була у м'ясо-яєчних курей вітчизняної селекції й вірогідно більшою порівняно 3 „росівською” птицею. У „кобівських” курей груп „К-11” і „К-51” заплідненість яєць також була вищою на 6,4-13,1\% (P>0,95), ніж у „росівських”. Найбільший вивід курчат відмічено у м'ясо-яєчних курей вихідної форми - 82,9\%, що більше на $2,4-3,8 \%$, ніж у „кобівських” гібридів та на 10,9-17,4\% (P>0,99) порівняно з „росівськими”. У „кобівських” курей груп „К-11” і „К-51” вивід курчат більший на 7,1-15,0\% (P>0,95), ніж у „росівських”.

3 одержаних експериментальних даних видно, що деякі важливі адаптивні ознаки (заплідненість яєць, вивід молодняку, збереженість молодняку та дорослого поголів'я) птиці двох нових мікроліній (умовно названих „кобівською” та „ро- сівською") були дещо нижчими, ніж у вихідної популяції. Тому було прийнято рішення про розширення та збагачення ії генофонду за рахунок інтрогресії генів від птиці створених мікроліній.

Для цього було сформовано з різних мікроліній групу особин, які стохастично спарювалися між собою. При цьому серед загального поголів'я цієї групи кількість самців і самок вихідної форми становила 50\%, а створених мікроліній („кобівської” та „росівської”) - по 25\% кожної. Теоретично передбачалося, що гарно пристосована до місцевих умов птиця вихідної популяції привнесе в новостворену групу м'ясо-яєчних курей, перш за все, добрі адаптивні та відтворні якості, тоді як півні і кури „кобівської” мікролінії будуть джерелом генів високої енергії росту та маси яєць, а „росівської" - інтродукують в новостворену синтетичну гетерогенну популяцію спадкові фрактори (алелі) високої несучості.

Проведені спостереження за адаптивними і продуктивними ознаками птиці новоствореної гетерогенної субпопуляції, умовно позначеної кодовою назвою як група „К-5”, в цілому підтвердили ці теоретичні міркування. Переважна більшість продуктивних ознак м'ясо-яєчних курей створеної синтетичної популяції „К-5” поліпшилися у порівнянні з попе- 
редніми поколіннями $\left(F_{9}-F_{11}\right)$ птиці вихідної базової популя- | ції (табл. 2).

Таблиця 2

Господарськи корисні ознаки м'ясо-яєчних курей в динаміці поколінь

\begin{tabular}{|c|c|c|c|c|}
\hline \multirow{2}{*}{ Продуктивні ознаки } & \multicolumn{4}{|c|}{ Генерація з початку проведення досліджень } \\
\hline & $F_{9}$ & $F_{10}$ & $\mathrm{~F}_{11}$ & $F_{12}$ \\
\hline Жива маса в 17-тижнів, кг: півні & 2,95 & 3,09 & $2,88^{a}$ & $3,19^{6}$ \\
\hline кури & 2,27 & 2,34 & $2,14^{\mathrm{B}}$ & $2,32\ulcorner$ \\
\hline Жива маса в 52-тижнів, кг: півні & 3,81 & 4,41 & $4,03^{a}$ & $4,54^{6}$ \\
\hline кури & 2,89म & 3,39 & $3,16^{\mathrm{B}}$ & $3,54^{\text {ге }}$ \\
\hline Маса яєць, г: у 24 тижні & 52,05 & 52,67 & 45,27 д & $53,18^{\mathrm{e}}$ \\
\hline 30 тижнів & 53,60 म & $56,39^{a}$ & 54,31 A & $57,596 \mathrm{e}$ \\
\hline 52 тижні & 59,91 д & 62,70 & 62,55 & $63,45^{\mathrm{e}}$ \\
\hline \multicolumn{5}{|l|}{ Несучість за 30 тижнів яйцекладки, яєць: } \\
\hline на початкову несучку & 89,1 & 101,0 & 101,7 & 116,3 \\
\hline на середню несучку & 90,4 & 101,8 & 102,3 & 116,6 \\
\hline Збереженість молодняку до 17-тижнів,\% & 90,7 & 90,6 & 92,9 & 97,9 \\
\hline Збереженість дорослого поголів'я, \% & 90,4 & 91,3 & 92,5 & 98,0 \\
\hline Заплідненість яєць, \% & 80,3 & 86,4 & 91,8 & 84,3 \\
\hline Виводимість яєць, \% & 91,2 & 95,2 & 90,3 & 90,8 \\
\hline Вивід молодняку, \% & 73,2 & 82,3 & 82,9 & 76,5 \\
\hline
\end{tabular}

Примітка: а:б - P>0,95; в:ट - P>0,99; d:e-P>0,999.

Так, порівняно з попередніми поколіннями збільшилася жива маса птиці в молодому (півників на 100-310 г, курочок - на 50-180 г) та дорослому віці (півнів на 130-730 г, курей на 150-650 г), маса яєць у різні вікові періоди, несучість (на початкову несучку на 14,5-27,2 яєць, на середню на 14,3-26,2 яєць), життєздатність молодняку ( на 5,0-7,3\%) і дорослого поголів'я (на 5,5-7,6\%). Відтворні якості курей створеної гетерогенної популяції були добрими. Заплідненість яєць становила 84,3\%, виводимість яєць - 90,8\%, вивід молодняку на рівні $76,5 \%$, що було вище або на рівні показників періоду досліджень.

Схрещування м'ясо-яєчних курей вітчизняної селекції з півнями м'ясних кросів закордонного походження дало

змогу отримати додаткову основну продукцію у розмірі 48,02 грн. на 1 голову внаслідок збільшення несучості птиці та 6,75-7,09 грн. на 1 голову при реалізації дорослих курей на м'ясо завдяки збільшенню їх живої маси у дорослому віці порівняно з вихідною формою.

Висновки. Схрещування півнів імпортних високопродуктивних м'ясних кросів «Кобб-500» і «Росс-308» з м'ясояєчними курми вітчизняної селекції сприяло покращенню їх адаптивних й продуктивних ознак, збільшенню рівня мінливості, що створює гарні передумови для підвищення генетичного потенціалу та комбінаційної здатності птиці локальної популяції.

\section{Список використаної літератури:}

1. Даниленко В. П. Науково-практичне обґрунтування методів формування високопродуктивного стада молочної худоби : авторефр. дис. ... канд. с.-г. наук:06.02.01

2. Калинка А. К., Шпак Л. В., Вдовиченко Ю. В. Формування стад м'ясного комолого симентала. Вісник аграрної науки. 2011. №8. С.34-38.

3. Лісний В. А. Лісна Т. М., Новицький В. І. Ефективність використання перспективного генофонду свиней у системі гібридизації. Таврійський науковий вісник. 2011. Вип. 76, ч. 2. С. 15-18.

4. Похил В., Похил О., Гончар А. М'ясні породи овець у Придніпров’ї. Тваринництво України. 2011. №9. С. 17-20.

5. Полупан Ю. П. Генетична детермінація ефективності довічного використання чорно-рябої молочної худоби. Розведення і генетика тварин. 2003. Вип. 35. С. 108-117.

6. Косинцев Ю., Анненкова М., Анненков В. Аутосексный яичный кросс кур «Птичное-2». Птицеводство. 2005. №7. C. 2-3.

7. Богатир В. П. Вплив ввідного схрещування на відтворні якості материнської лінії колорсексного кросу. Птахівництво. 2004. Вип. 55. С. 32-37.

8. Гальперн И., Синичкин В., Слепухин В. Клеточная технология содержания мясных кроссов. Птицеводство. 2009. №6. C. $22-23$.

9. Мальцев А. В., Дымков А. В. Приемы селекции при создании линии породы корниш. Актуальные проблемы современного птицеводства: материалы Х Укр. конф. по птиц-ву с международ. уч., м. Алушта, 15-18 вер., 2009. Харків, 2009. C. $236-240$.

20.

10. Ройтер Я. Роль генофонда в создании новых пород и кроссов. Животноводство России. 2010. №1. S. 19 -

11. Гадючко О., Рябоконь Ю., Катеринич О. Стресостійкі лінії індиків вітчизняної селекції. Птахівництво. 2006. Вип. 58. С. $49-62$.

12. Тучемский Л. И., Гладкова Г. В., Емануилова Ж. В. Приемы селекции линии аутосексного кросса мясных кур

«Смена 7». Достижения в современном птицеводстве: исследования и инновации: мат. XVI конф. ВНАП, Сергиев

Посад, 2009. С. $64-66$. 
13. Прибузький М. Кроси м'ясної птиці. Наше птахівництво. 2012. №1. С. 26 - 27.

14. Степаненко І. А. Характеристика генетичних ресурсів птиці в птахогосподарствах України. Сучасне птахівництво. 2009. №8(81). С. 5 - 9.

\section{References:}

1. Danylenko, V. P., 2007. Scientific and practical substantiation of methods for the formation of a highly productive herd of dairy cattle. Abstract of Ph.D. dissertation. Chubynske, Kyiv region.

2. Kalynka, A. K., Shpak, L. V. and Vdovychenko, Ju. V., 2011. Formuvannja stad m'jasnogo komologo symentala [Formation herds of meat hornless Simmental]. Visnyk agrarnoi' nauky, no. 8, pp. 34 - 38.

3. Lisnyj, V. A., Lisna, T. M. and Novyc'kyj, V. I., 2011. Efektyvnist' vykorystannja perspektyvnogo genofondu svynej u systemi gibrydyzacii [The efficiency of using perspective gene pool of pigs in the hybridization system]. Tavrijs'kyj naukovyj visnyk, issue 76(2), pp. $15-18$.

4. Pohyl, V., Pohyl, O. and Gonchar, A., 2011. M'jasni porody ovec' u Prydniprov'i' [Meat breeds of sheep in the Dnieper region]. Tvarynnyctvo Ukrai'ny, no. 9, pp. $17-20$.

5. Polupan., Ju. P., 2003. Genetychna determinacija efektyvnosti dovichnogo vykorystannja chorno-rjaboi' molochnoi' hudoby [Genetic determination of the effectiveness of lifetime use of Black-and-White dairy cattle]. Rozvedennja i genetyka tvaryn, issue 35, pp. $108-117$.

6. Kosincev, Ju., Annenkova, M. and Annenkov, V., 2005. Autoseksnyj jaichnyj kross kur „Ptichnoe-2” [Autosex egg cross of chickens "Ptichnoe-2"]. Pticevodstvo, no. 7, pp. 2-3.

7. Bogatyr, V. P., 2004. Vplyv vvidnogo shreshhuvannja na vidtvorni jakosti materyns'koi' linii' kolorseksnogo krosu [Influence of introductory crossing on reproductive qualities of maternal line of color cross]. Ptahivnyctvo, issue 55. pp. $32-37$.

8. Gal'pern, I., Sinichkin, V. and Slepuhin, V., 2009. Kletochnaja tehnologija soderzhanija mjasnyh krossov [Cell technology for keeping meat crosses]. Pticevodstvo, no. 6, pp. 22 - 23.

9. Mal'cev, A. B. and Dymkov, A. B., 2009. Priemy selekcii pri sozdanii linii porody kornish [Breeding techniques for creating a Cornish line]. In: Kharkov, Actual problems of modern poultry farming, materials of the X Ukrainian conf., Alyshta, September 15-18, Kharkov, pp. 236-240.

10. Rojter, Ja., 2010. Rol' genofonda v sozdanii novyh porod i krossov [The role of gene pool in the creation of new breeds and crosses]. Zhivotnovodstvo Rossii, no. 1, pp. $19-20$.

11. Gadjuchko, O., Rjabokon', Ju. and Katerynych, O., 2006. Stresostijki linii' indykiv vitchyznjanoi' selekcii' [Stressresistant lines of turkeys of domestic selection]. Ptahivnyctvo, issue 58, pp. $49-62$.

12. Tuchemskij, L. I., Gladkova, G. V. and Emanujlova, Zh. V., 2009. Priemy selekcii linij autoseksnogo krossa mjasnyh kur „Smena7” [Breeding techniques for the line of autosex cross of meat chickens "Smena 7"]. In: Sergiev Posad, Advances in Modern Poultry: research and innovation, materials of the XVI VNAP., Sergiev Posad, pp. 64 - 66.

13. Prybuz'ky], M., 2012. Krosy m'jasnoi' ptyci [Meatbird crosses]. Nashe ptahivnyctvo, no. 1, pp. 26 - 27.

14. Stepanenko, I. A., 2009. Harakterystyka genetychnyh resursiv ptyci u ptahogospodarstvah Ukrai'ny [Characteristics of poultry genetic resources in poultry farms of Ukraine]. Suchasne ptahivnyctvo, no. 8(81). pp. 5 - 9.

Bondarenko Yuriy Vasyleevich, Doctor of Biological Sciences, Professor, Sumy National Agrarian University NAAS

Khvostik Victor Pfvlovich, Doctor of Agricultural Sciences, Institute of Animal Breeding and Genetics nd. a. M.V.Zubets of

\section{Improving the productivity of domestic meat and egg chickens}

The work was performed on meat and egg chickens of domestic selection, breeding work with which was carried out in the DDSP NAAN. With prolonged breeding "in itself" by methods of mass selection, the economically useful characteristics of meat and egg chickens of domestic selection have deteriorated somewhat. In this regard, an urgent need arose to improve the main productive characteristics of meat and egg chickens by crossing highly productive crosses of foreign selection with poultry. Crossings of meat and egg chickens with males of the parental form of the Cobb-500 cross significantly increased the live weight of $F_{1}$ hybrid offspring, the weight of eggs at 52 weeks of age, but decreased egg production compared to the initial base population. Hybridization of meat and egg chickens with roosters of the Ross-308 cross only increased the growth energy of $F_{1}$ young stock up to 10 weeks of age. Breeding $F_{1}$ hybrids "in itself" and reverse crossing of $F_{1}$ females with over-eaten males of the "Cobb-500" cross contributed to an increase in live weight in $F_{2}$ offspring, egg weight, but at the same time reduced egg production by 7.7-10.1 eggs (or 8.19-11.03\%) compared to the original maternal form. Breeding "Ross" $F_{1}$ birds "in itself" and reverse crossing of hybrid $F_{1}$ females with roasted roosters of the Ross-308 cross helped to improve the live weight of $F_{2}$ offspring by $5.21-11.89 \%$, egg production by $6.2-7.4$ eggs in comparison with meat and egg hens of the base population. When poultry of different genotypic groups were combined, a heterogeneous subpopulation was created, the productive characteristics of which improved in comparison with previous generations $\left(F_{9}-F_{11}\right)$ of the original basic population. In comparison with previous generations, the live weight of poultry increased in young (males by 100-310 g, chickens by 50-180 g) and adult (males by 130-730 g, chickens by 150-650 g), the weight of eggs in different age periods, egg production (for the initial hen by 14.5-27.2 eggs, for the average hen - by 14.3-26.2 eggs), the viability of young stock (by 5.0-7.3\%) and adult livestock (by 5.5-7.6\%). The reproductive qualities of the chickens of the created heterogeneous population were good.

Key words: meat and egg chickens, economically useful traits, roosters of imported meat crosses, crosses.

Дата надходження до редакції: 03.10.2020 р. 